\title{
Chrysobrycon yoliae, a new species of stevardiin (Characiformes: Characidae) from the Ucayali basin, Peru
}

\author{
James Anyelo Vanegas-Ríos ${ }^{1}$, María de las Mercedes Azpelicueta ${ }^{1}$ and Hernán Ortega ${ }^{2}$
}

\begin{abstract}
Chrysobrycon yoliae, new species, is described from a drainage flowing into the río Yucamia basin, río Ucayali basin, Peru. Chrysobrycon yoliae is readily distinguished from its congeners by the anterior tip of pelvic bone situated anterior to the fifth rib (vs. situated posterior to the fifth rib), the presence of 20-26 dentary teeth (vs. 11-19), and the possession of a terminal lateral-line tube between caudal-fin rays 10 and 11 (vs. the absence of this tube, except in C. eliasi). The new species differs from C. eliasi and C. myersi by the presence of teeth on third pharyngobranchial (vs. the absence of teeth on this bone) and also differs from C. eliasi by the dorsal-fin origin situated at vertical through anal-fin rays 5 to 7 (vs. located at vertical through anal-fin rays 8 to 10), the posterior extent of the ventral process of quadrate reaching the vertical through posterior margin of symplectic ( $v s$. not reaching the vertical through posterior margin of symplectic), the dorsal-fin to adipose-fin length $26.8-28.8 \%$ SL (vs. 23.9-26.8\% SL), and the body depth at dorsal-fin origin 34.4-42.2\% SL (vs. 24.1-34.5\% SL). A key for the identification of Chrysobrycon species is provided.
\end{abstract}

Se describe Chrysobrycon yoliae, una nueva especie de un drenaje que fluye hacia la cuenca del río Yucamia, cuenca del río Ucayali, Perú. Chrysobrycon yoliae es fácilmente distinguible de sus congéneres por la punta anterior del hueso pélvico situada anterior a la quinta costilla (vs. situada posterior a la quinta costilla), la presencia de 20-26 dientes dentarios (vs. 11-19) y la presencia de tubo terminal de la línea lateral entre los radios caudales 10 y 11 ( $v$ s. la ausencia de este tubo, excepto en C. eliasi). La nueva especie difiere de C. eliasi y C. myersi por el desarrollo de dientes sobre el tercer faringobranquial (vs. la ausencia de dientes sobre este hueso) y también difiere de C. eliasi por el origen de la aleta dorsal ubicado en la vertical a través de los radios anales 5 a 7 (vs. ubicado en la vertical a través de los radios anales 8 a 10), por la extensión posterior del proceso ventral del cuadrado que alcanza la vertical que pasa por el margen posterior del simpléctico ( $v s$. no alcanza la vertical que pasa por el borde posterior del simpléctico), por la distancia aleta dorsal-aleta adiposa 26,8-28,8\% LE (vs. 23,9-26,8\% LE) y la altura del cuerpo en el origen de aleta dorsal 34,4-42,2\% LE (vs. 24,1-34,5\% LE). Se provee una clave para la identificación de las especies de Chrysobrycon.

Key words: Xenurobryconini, Pit organs, Amazon basin, Pouch scale, Sexual dimorphism.

\section{Introduction}

Chrysobrycon Weitzman \& Menezes is diagnosed by a characteristic pouch scale on the ventral lobe of the caudal fin in mature males (Weitzman \& Menezes, 1998). This pouch scale is relatively small, somewhat elongated, curved, and horizontally folded so that its lateral face forms a laterally concave, broadly open pocket (Weitzman \& Menezes, 1998). In fact, this type of pouch scale is unique within the Xenurobryconini (Weitzman \& Fink, 1985), a tribe in which Weitzman \& Menezes (1998) classified the genus.
Chrysobrycon has three valid species: C. eliasi VanegasRíos, Azpelicueta \& Ortega, C. hesperus (Böhlke), and C. myersi Weitzman \& Menezes (Böhlke, 1958; Weitzman \& Thomerson, 1970; Vanegas-Ríos et al., 2011). Chrysobrycon hesperus is the type species of the genus and was originally described for the río Napo basin in Ecuador (Böhlke, 1958). Chrysobrycon myersi, a species distributed more southward than C. hesperus, is known from the río Pachitea basin in Peru (Weitzman \& Thomerson, 1970). Chrysobrycon eliasi occurs along several localities flowing into the río Madre de Dios and upper río Manuripe basins in Peru (Vanegas-Ríos et al., 2011).

${ }^{1}$ Consejo Nacional de Investigaciones Científicas y Técnicas (CONICET), División Zoología de Vertebrados, Facultad de Ciencias Naturales y Museo, Paseo del Bosque S/N B1900FWA, La Plata, Buenos Aires, Argentina. anyelovr@fcnym.unlp.edu.ar, azpelicueta@gmail.com.ar ${ }_{2}^{2}$ Departamento de Ictiología, Museo de Historia Natural, Universidad Nacional Mayor de San Marcos, PO Box 14-0434, Lima - 14, Peru. hortega.musm@gmail.com 
Chrysobrycon species are strictly cis-Andean occurring in freshwater ecosystems between 153 and $585 \mathrm{~m}$ above sea level (a.s.l.) in the upper Amazon basin in Colombia, Ecuador, and Peru (Böhlke, 1958; Weitzman \& Thomerson, 1970; VanegasRíos et al., 2011; Vanegas-Ríos et al., 2013b). According to Weitzman \& Thomerson (1970), Vanegas-Ríos et al. (2011), and Vanegas-Ríos et al. (2013b), C. myersi is the only species that occurs in the río Ucayali basin. Chrysobrycon myersi is easily distinguished within the genus not only by its secondary sexually dimorphic characters in males (e.g., spinelets on pelvic-, anal-, and caudal-fin rays), but also by meristic and morphometric differences (Weitzman \& Thomerson, 1970; Vanegas-Ríos et al., 2011). We examined several specimens from an unnamed drainage flowing into the río Yucamia system (río Ucayali basin) that did not correspond to the described species of Chrysobrycon. Therefore, we describe these specimens as a new species of Chrysobrycon and provide a key to identify the species of the genus.

\section{Material and Methods}

The studied specimens are deposited in the collections of Asociación Ictiológica, La Plata (AI); Academy of Natural Sciences of Drexel University, Philadelphia (ANSP), Fundación Miguel Lillo, Tucumán (CI-FML); Natural History Museum of Los Angeles County, Los Angeles (LACM); Museo de Historia Natural de la Universidad Nacional Mayor de San Marcos, Lima (MUSM); Museo de La Plata, La Plata (MLP); and National Museum of Natural History, Smithsonian Institution, Washington, D.C. (USNM). Counts of the pectoral-, pelvic- and dorsal-fin rays are presented according to Böhlke (1958). Measurements and other counts follow Fink \& Weitzman (1974) and Menezes \& Weitzman (2009), with the addition of measurements described by Vanegas-Ríos et al. (2013a). The gill-gland length was measured in males from its anterior to its posterior margins of fused gill filaments. Measurements were taken point to point with digital caliper under stereomicroscope and are expressed as percentages of standard length (SL) or head length (HL) for units of the head.

Frequency of a particular character value is presented in parentheses with the holotype value indicated by an asterisk. The scales of the median dorsal row and the small scales situated just below the insertion of the anteriormost dorsalfin ray are excluded from the counts of longitudinal scale rows between the dorsal fin and lateral line. Specimens were cleared and counterstained (c\&s) following Taylor \& Van Dyke (1985). Total vertebral counts were determined in c\&s specimens. These include the first preural centrum plus first ural centrum (PU1+U1) counted as one element and the four vertebrae of the Weberian apparatus. Pleural ribs counted according to the vertebral counts (i.e., the rib of the fifth vertebra corresponds to the fifth rib). A key including all Chrysobrycon species, which was modified from VanegasRíos et al. (2011), is provided on the basis of the examined material and data from literature (Böhlke, 1958; Weitzman \& Thomerson, 1970).

Statistical tests and regression plots (as function of size) were performed using PAST 2.15 (Hammer et al., 2001) and SigmaPlot 10.0 for Windows (2006, Systat Software, Inc.) for measurements showing a sexually dimorphic pattern. The results of these analyses are presented in the section of sexual dimorphism.

\section{Results}

\section{Chrysobrycon yoliae, new species Figs. 1-6a}

Holotype. MUSM 46140, $51.6 \mathrm{~mm} \mathrm{SL}$, male, Peru, Ucayali, Coronel Portillo, Abujao, río Ucayali basin, río Yucamia subsystem, unnamed Quebrada, $8^{\circ} 39^{\prime} 13.99^{\prime}$ 'S $73^{\circ} 21^{\prime} 16.63^{\prime \prime} \mathrm{W}$, approximately 273 m a.s.l., 4 Oct 2008, F. Cari \& I. Gamboa.

Paratypes. All from Peru. CI-FML 5882, 3, 44.8-52.3 mm SL (1 c\&s, $44.8 \mathrm{~mm} \mathrm{SL);} \mathrm{MLP} \mathrm{10517,} \mathrm{1,} 48.4$ mm SL; MUSM 46141, 8, 38.2-51.5 mm SL, all collected with holotype.

Diagnosis. Chrysobrycon yoliae is readily distinguished from its congeners by the anterior tip of pelvic bone situated anterior to the fifth rib (vs. situated posterior to the fifth rib), the presence of 20-26 dentary teeth (vs. 12-19 in C. eliasi, 11-19 in C. hesperus, and 12-18 in C. myersi), and the possession of a terminal lateral-line tube between caudalfin rays 10 and 11 (vs. the absence of this tube, except in $C$. eliasi). Chrysobrycon yoliae differs from C. eliasi and $C$. myersi by the presence of teeth on third pharyngobranchial (vs. the absence of teeth on this bone). Chrysobrycon yoliae is also distinguished from C. eliasi by the dorsal-fin origin situated vertically between anal-fin rays 5 to 7 (vs. situated vertically between anal-fin rays 8 to 10 ), the posterior extent of the ventral process of quadrate reaching the vertical through posterior margin of symplectic (vs. not reaching the vertical through posterior margin of symplectic), the dorsalfin to adipose-fin length $26.8-28.8 \%$ SL (vs. 23.9-26.8\% $\mathrm{SL}$ ), and the body depth at dorsal-fin origin $34.4-42.2 \% \mathrm{SL}$ (vs. 24.1-34.5\% SL). Furthermore, Chrysobrycon yoliae is distinguished from $C$. hesperus by the absence of minute bony hooks on distal portion of the anal-fin rays in adult males (vs. the presence of a series of such hooks on distal portion of almost all anal-fin rays). Chrysobrycon yoliae also differs from C. myersi by the dorsal-fin to pectoral-fin length 47.3-53.1\% SL (vs. 43.0-46.1\% SL), the eye to dorsal-fin origin length $49.6-55.0 \% \mathrm{SL}$ (vs. $45.8-49.2 \% \mathrm{SL}$ ), the upper 
jaw length 44.9-48.1\% HL (vs. 48.9-55.0\% HL), the number of circumpeduncular scales 15-16 (vs. 17-19), and the number of branched anal-fin rays 26-28 (vs. 33-39).

Description. Morphometric data in Table 1. Largest male $52.3 \mathrm{~mm}$ SL and largest female $51.5 \mathrm{~mm}$ SL. Body laterally compressed, with maximum depth at vertical through onehalf the length of pelvic fin (Fig. 1). Dorsal profile of body straight over head, slightly concave on supraoccipital area and convex from that area to dorsal-fin origin, straight and slanting ventrally from first dorsal-fin ray to caudal peduncle. Dorsal profile of caudal peduncle slightly concave or straight. Ventral profile of body convex from tip of snout to pelvicfin origin, straight between paired fins, straight and slanting dorsally from anal-fin origin to caudal peduncle. Ventral profile of caudal peduncle straight or slightly concave. Head with anterior region acute. Frontal fontanel absent. Epiphyseal branch of supraorbital canal absent. Anterior nostril rounded and separated by one skin fold from posterior one; posterior opening larger. Two pit organs developed in grooves of head; anterior groove rounded, located between nasal and nostril; posterior groove extended along frontal, from region medial to nares to vertical through posterior portion of orbit, covered with lines of neuromasts.

Dorsal-fin rays $\mathrm{ii}, 8 *$ in all specimens. Nine proximal pterygiophores on dorsal fin ( $1 \mathrm{c} \& s)$. Dorsal-fin origin located at vertical between anal-fin rays 5-7. Adipose fin located at vertical between second and third posteriormost anal-fin ray. Anal-fin rays iv(7) or v*(6), 26*(4), 27(3), or 28(6). Twentyeight proximal pterygiophores on anal fin ( $1 \mathrm{c} \& \mathrm{~s})$. Anal-fin origin situated in posterior half of body, always anterior to vertical through dorsal-fin origin. Pectoral-fin rays i(13), $8(1), 9 *(8), 10(3)$, or 11(1). Pectoral fin long, its posterior tip reaching one-third to one-half of pelvic-fin length (Fig. 1). Pelvic-fin rays i,7 in all specimens; last pelvic-fin ray unbranched in nine specimens but counted as branched. Pelvic-fin origin slightly anterior to half of body. Caudal fin forked with 10/9 principal rays in all specimens.

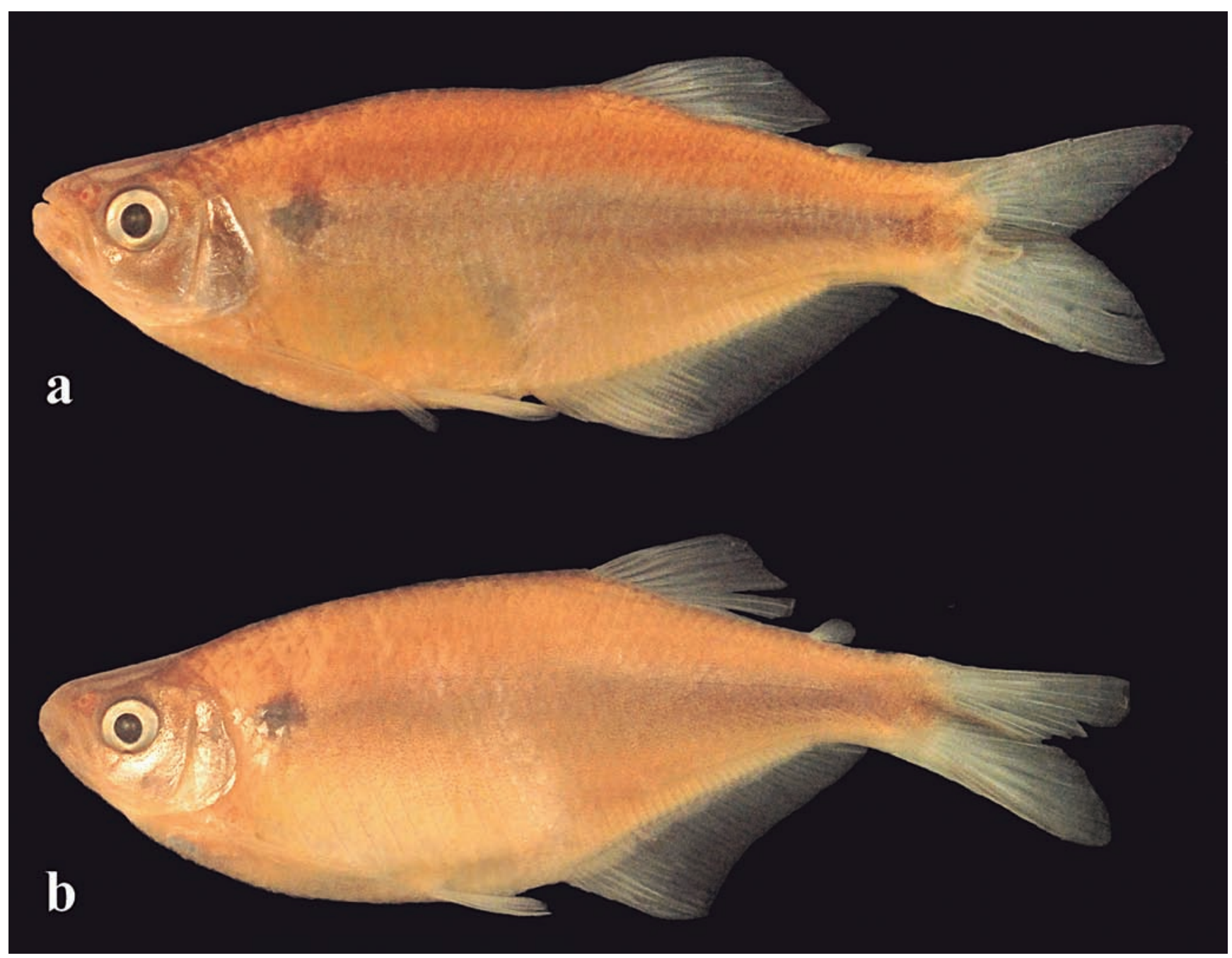

Fig. 1. Chrysobrycon yoliae, (a) MUSM 46140, holotype male, $51.6 \mathrm{~mm}$ SL, Peru, Ucayali, Coronel Portillo, Abujao, río Ucayali basin, río Yucamia system, unnamed Quebrada; (b) MUSM 46141, paratype female, 51.5 mm SL, collected with holotype. 
Table 1. Morphometric data of holotype and 12 paratypes of Chrysobrycon yoliae (five males and eight females) from an unnamed Quebrada, río Yucamia system, Ucayali basin, Peru. SD = standard deviation. The values of the holotype are included in the range of males.

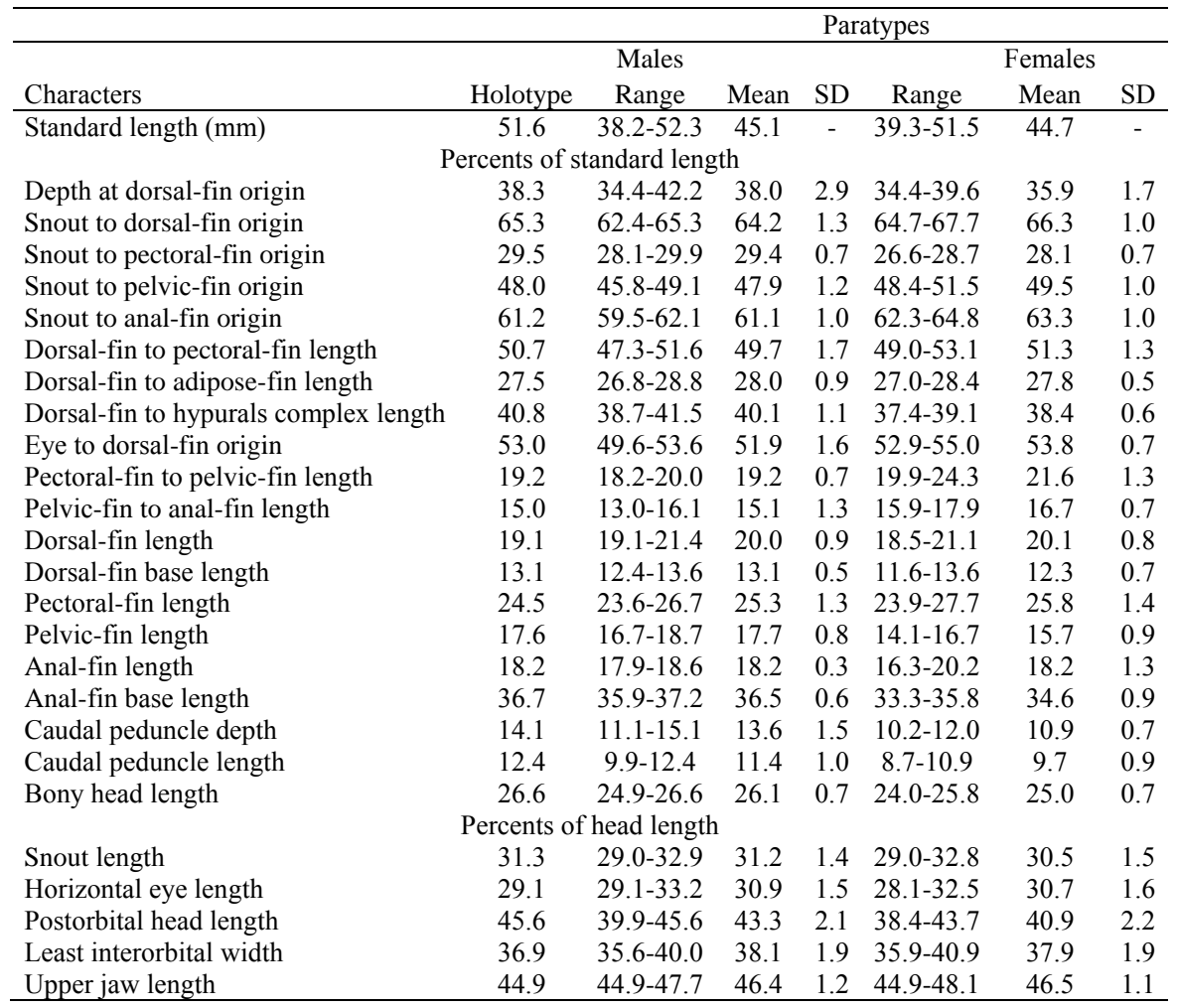

Mouth superior, lower jaw projecting slightly anterior to upper jaw. Premaxilla with two rows of teeth. Outer row with $3(1), 4(6), 5^{*}(5)$, or 6(1) teeth; usually tricuspidate, conical to tetracuspidate in two specimens. Inner row with $4 *(9)$ or 5(4) teeth, symphyseal tooth tetracuspidate, remaining teeth pentacuspidate, except posteriormost tricuspidate. Maxilla with 9(2), 10(2), 11(2), 12*(2), 14(2), 15(1), or 16(2) teeth. Anteriormost first to fifth teeth of maxilla usually tricuspidate, rarely conical, bicuspidate or tetracuspidate, remaining teeth conical (Fig. 2a). Maxilla bearing teeth along more than $60 \%$ of its length in adults. Maxilla relatively short, not reaching vertical through anterior border of pupil. Dentary with 20(3), 21(3), $22 *(2), 23(2), 25(1), 26(1)$, or 27(1) teeth, three anteriormost teeth large and pentacuspidate, one median-sized tooth usually tetracuspidate followed by 16(3), 17(3), 18*(2), 19(2), 21(1), 22(1), or 23(1) smaller conical posterior teeth (Fig. 2b).

Scales cycloid, with several radii along posterior field. Lateral line complete, pored scales 40(3), 41(3), 42*(4), 43(1), 44(1), or 45(1). Terminal lateral-line tube present on caudal-fin membrane. Predorsal scales 17(1), 19*(3), 20(8), or 22(1). Scale rows between dorsal fin and lateral line 6(5) or $7 *(8)$. Scale rows between lateral line and anal fin $5(6)$ or $6^{*}(7)$. Scale rows between lateral line and pelvic fin $5^{*}(9)$ or 6(4). Circumpeduncular scales $15^{*}(10)$ or $16(3)$. One row of 17(2), 18(3), 19(1), 20(2), 21(3), 23*(1), or 24(1) scales forming sheath along anal-fin base, such sheath usually with an additional second row of scales partially covering anal-fin base. Total number of vertebrae $41(1 \mathrm{c} \& \mathrm{~s}), 15$ precaudal and 26 caudal. Gill rakers on dorsal limb of first branchial arch $5(5)$ or $6 *(8)$, ventral limb with $11 *(5)$ or $12(8)$.

Color in alcohol. Ground color pale yellowish in preserved males and females, scarcely darker dorsally. Scattered dark brown and black chromatophores over all body, more concentrated dorsally, sometimes forming reticulate pattern. Black chromatophores forming one narrow line along middorsal. One narrow line of black chromatophores crossing mid-flank just one scale above of pored lateral-line scales. Lateral band iridescent brownish, extended from posterior region of humeral spot to end of caudal peduncle. In some specimens, caudal peduncle region bearing black and dark brown chromatophores forming somewhat triangular blotch. Black chromatophores forming stripes over myomeres, especially on posterior ventral one-third of body. Humeral spot somewhat rounded, slightly enlarged ventrally in few specimens. Dorsal fin hyaline, with disperse black chromatophores completely scattered on membranes, more concentrated on distal portion and on first ray. Adipose fin hyaline, sometimes with black chromatophores on its base. Anal fin hyaline, with chromatophores located on membranes, 


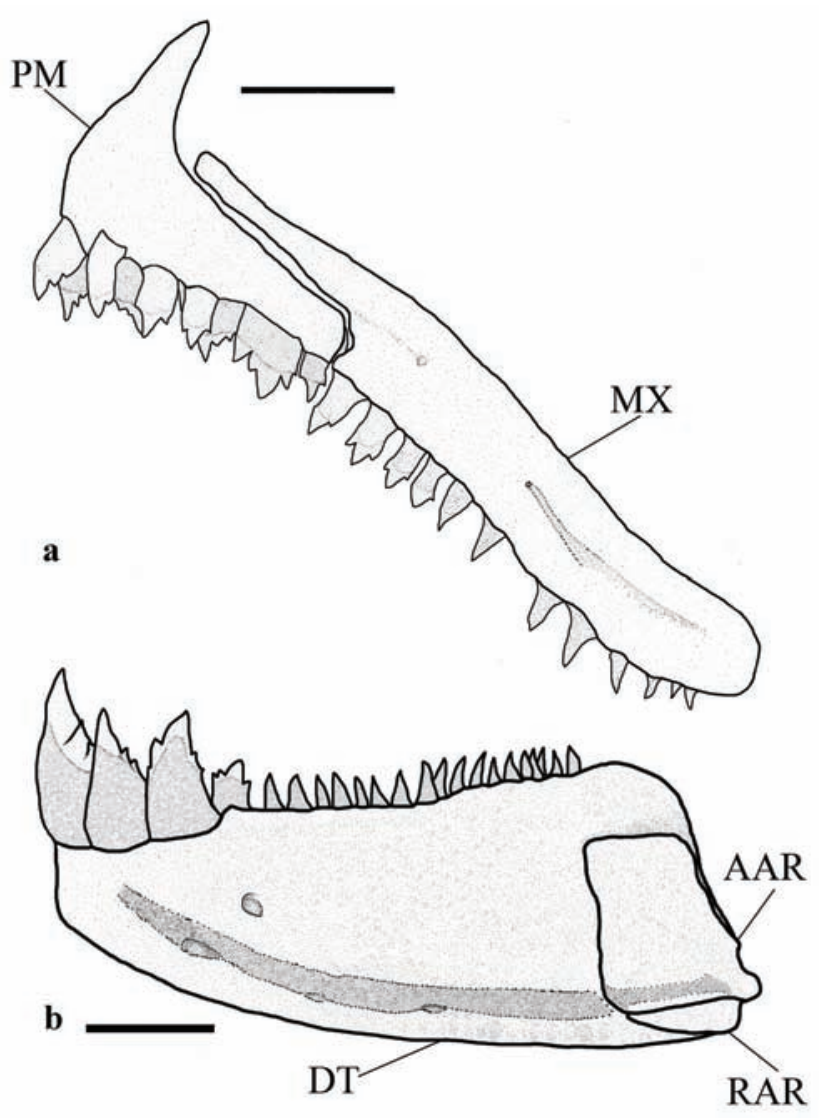

Fig. 2. Chrysobrycon yoliae, CI-FML 5882, paratype male, 44.8 mm SL. Lateral view of jaws: (a) Premaxilla (PM) and maxilla (MX), left side. (b) Dentary (DT), anguloarticular (AAR) and retroarticular bones (RAR), left side. Scale bar $=1 \mathrm{~mm}$. more concentrated on distal portion of rays, forming dusky distal area. Caudal fin bearing black chromatophores along membranes and few on rays; concentration of chromatophores on upper- and lowermost rays and middle rays of both lobes, especially on ventral one. Pectoral and pelvic fins hyaline with scattered black chromatophores. Head dark brown dorsally and yellowish ventrally, posterior half of head silvery. Opercle and infraorbitals completely covered by large dark brown chromatophores. Maxilla with few scattered chromatophores. Premaxilla covered by small dark brown chromatophores. Lower jaw with many small dark brown chromatophores. Snout heavily covered by black chromatophores.

Sexual dimorphism. Males and females differing by presence of bony hooks on caudal-, pelvic- and anal-fin rays. Caudal fin with 6-24 tiny hooks on each ray; usually paired and anterodorsally oriented on posterior one-half of rays 13-17. All rays of pelvic fin with short, slender hooks, anteroventrally placed along almost entire length of rays; usually two pairs per segment, and more numerous on medial rays. Anal fin bearing 5-11 husky hooks on each ray, usually one pair per segment, anterodorsally placed on posteriormost unbranched ray and branched rays 1-11; number of hooks increasing in middle rays. Lower lobe of caudal fin of males, but not of females, bearing several scales forming a broadly open pouch. Pouch opening mainly formed by single pouch scale with at least two accessories scales (Fig. 3). Pouch scale relatively small, somewhat elongate, curved and weakly horizontally folded

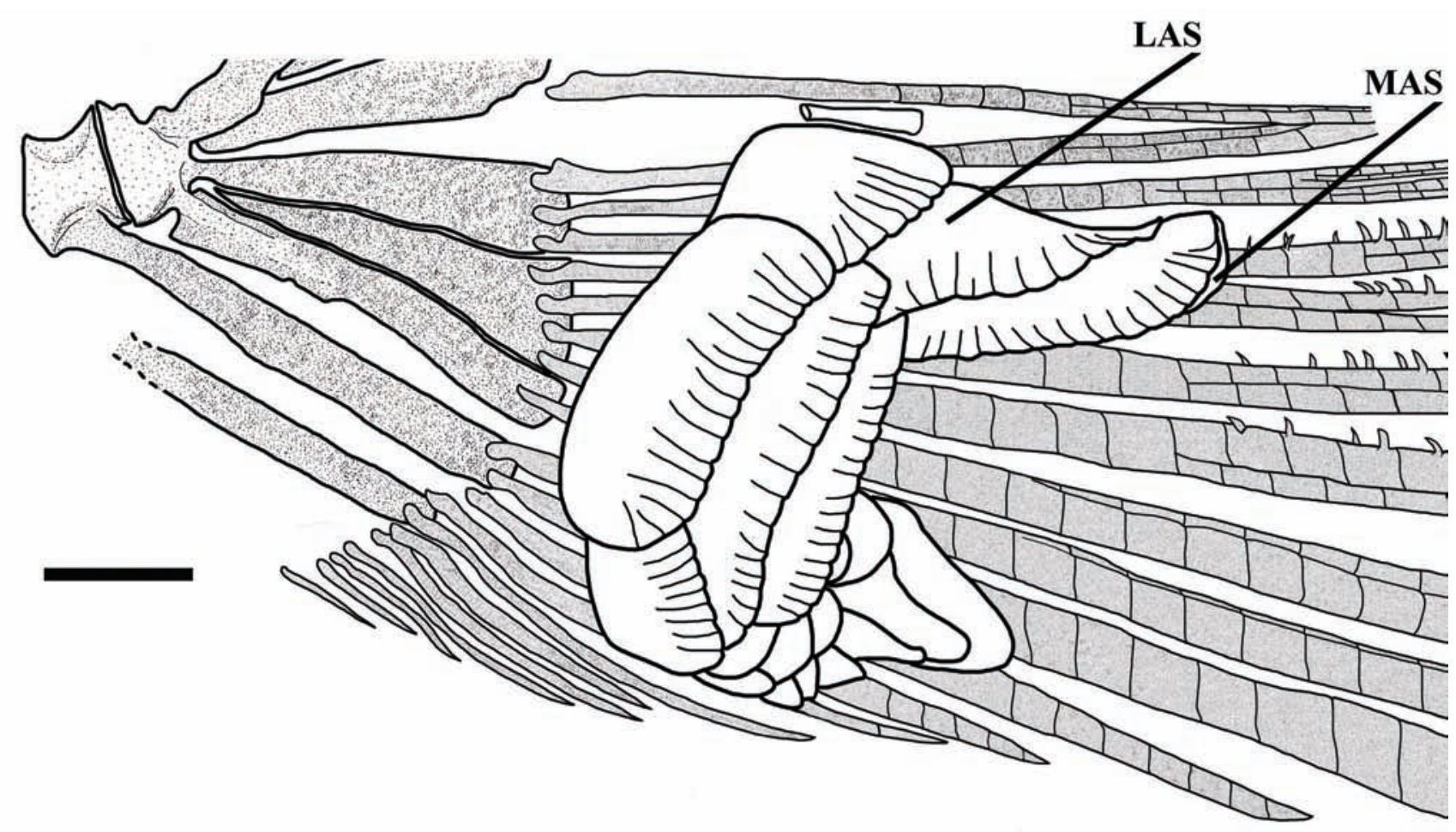

Fig. 3. Chrysobrycon yoliae, paratype male, CI-FML 5882, $44.8 \mathrm{~mm}$ SL. Lateral view of the ventral lobe of caudal fin, left side. Note the scales forming the pouch in this lobe. MAS: Medial accessory scale, LAS: Lateral accessory scale. Scale bar $=1 \mathrm{~mm}$. 
with its lateral face forming concave open pouch. Pouch with medial accessory scale somewhat curved, elongate and located under lateral face of pouch scale (partially visible in lateral view). Pouch with lateral accessory scale large, somewhat elongate posterodorsally and forming part of its laterodorsal region. Pouch scale and lateral accessory scale independent but in contact, both scales strongly attached to each other dorsally through well-developed medial mass of connective tissue. Caudal-fin rays 15 to 18 and anterolateral surface of pouch scale of males with small pieces of apparent glandular tissue.

Gill gland of males relatively long and formed by fusion of anterior $12(1), 13^{*}(2), 14(1)$, or 15(1) gill filaments of ventral limb of first gill arch. Total number of ventral limb gill filaments 25(1), 28(3), or 29*(1). Gill gland length between 4.7 and $6.9 \% \mathrm{SL}$ (mean $=5.5 \% \mathrm{SL}$ ), $5.1 \% \mathrm{SL}^{*}$. Snout to pectoralfin origin, snout to anal-fin origin, pectoral-fin to pelvic-fin length, and pelvic-fin length sexually dimorphic as function of SL and with differences more pronounced in larger specimens (Fig. 4). Males with higher values than females in snout to pectoral-fin origin and pelvic-fin length, while females with higher values in remaining two measurements.

Distribution. Chrysobrycon yoliae is known from its type locality, an unnamed drainage flowing into the río Yucamia system, río Ucayali basin, Peru (Fig. 5).

Ecological notes. The type locality is a white-water drainage with an average width of $3 \mathrm{~m}$ and depth between 0.3 and 1.6 $\mathrm{m}$ (very narrow shore). The water color is beige, rather clear and showing at least $20 \mathrm{~cm}$ of transparency. The velocity of current is moderate. The substrate is mainly sandy $(80 \%)$ and covered by pebbles $(20 \%)$. The riverine vegetation is mainly
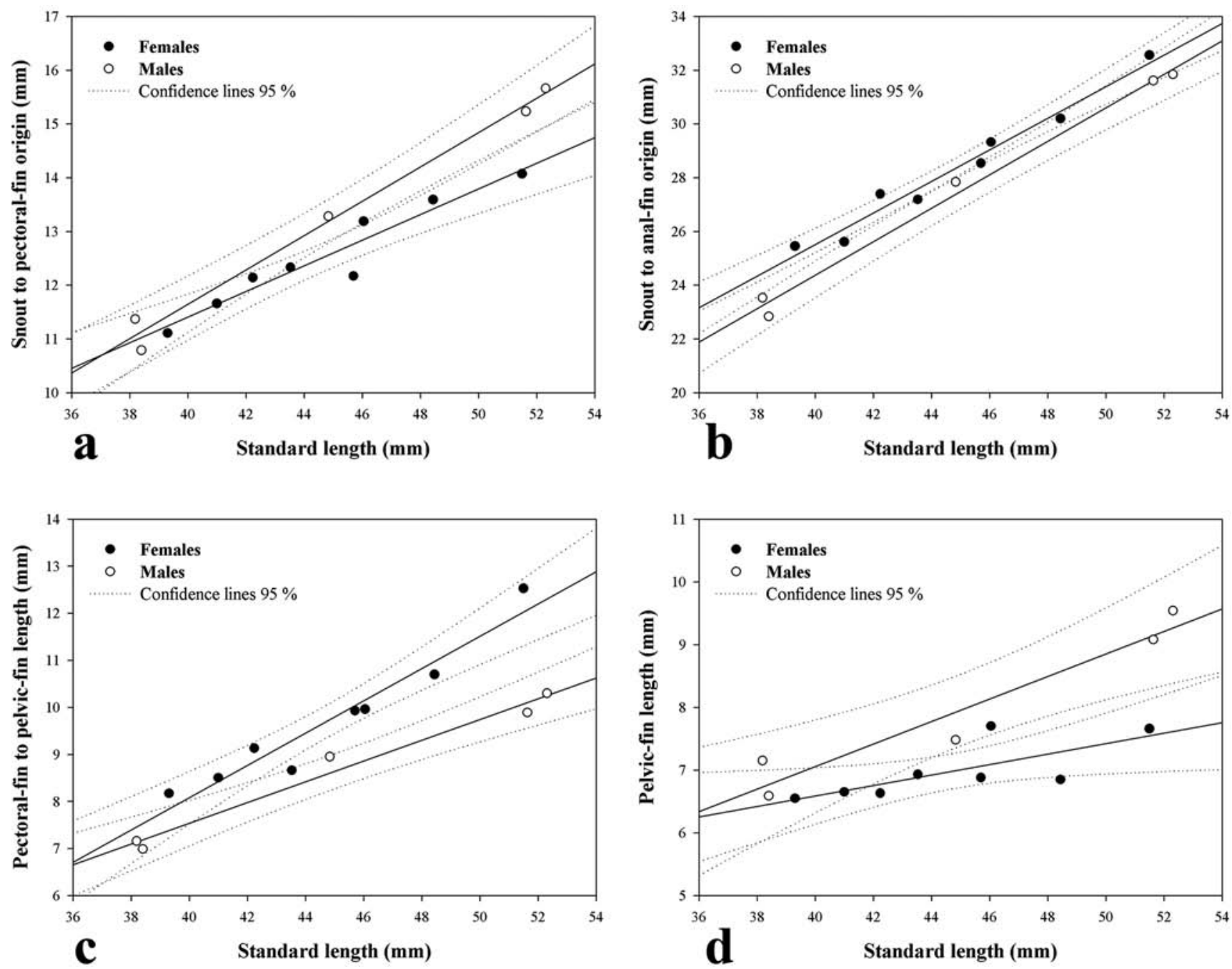

Fig. 4. Comparative regression plots of females $(n=8)$ and males $(n=5)$ of Chrysobrycon yoliae. All variables as function of SL: (a) Snout to pectoral-fin origin (females: $\mathrm{r}^{2}=0.92$; males: $\mathrm{r}^{2}=0.99$ ), (b) snout to anal-fin origin (females: $\mathrm{r}^{2}=0.97$; males: $r^{2}=0.99$ ), (c) pectoral-fin to pelvic-fin length (females: $r^{2}=0.93$; males: $r^{2}=0.98$ ), (d) pelvic-fin length (females: $r^{2}$ $=0.55$; males: $\left.\mathrm{r}^{2}=0.93\right)$. 


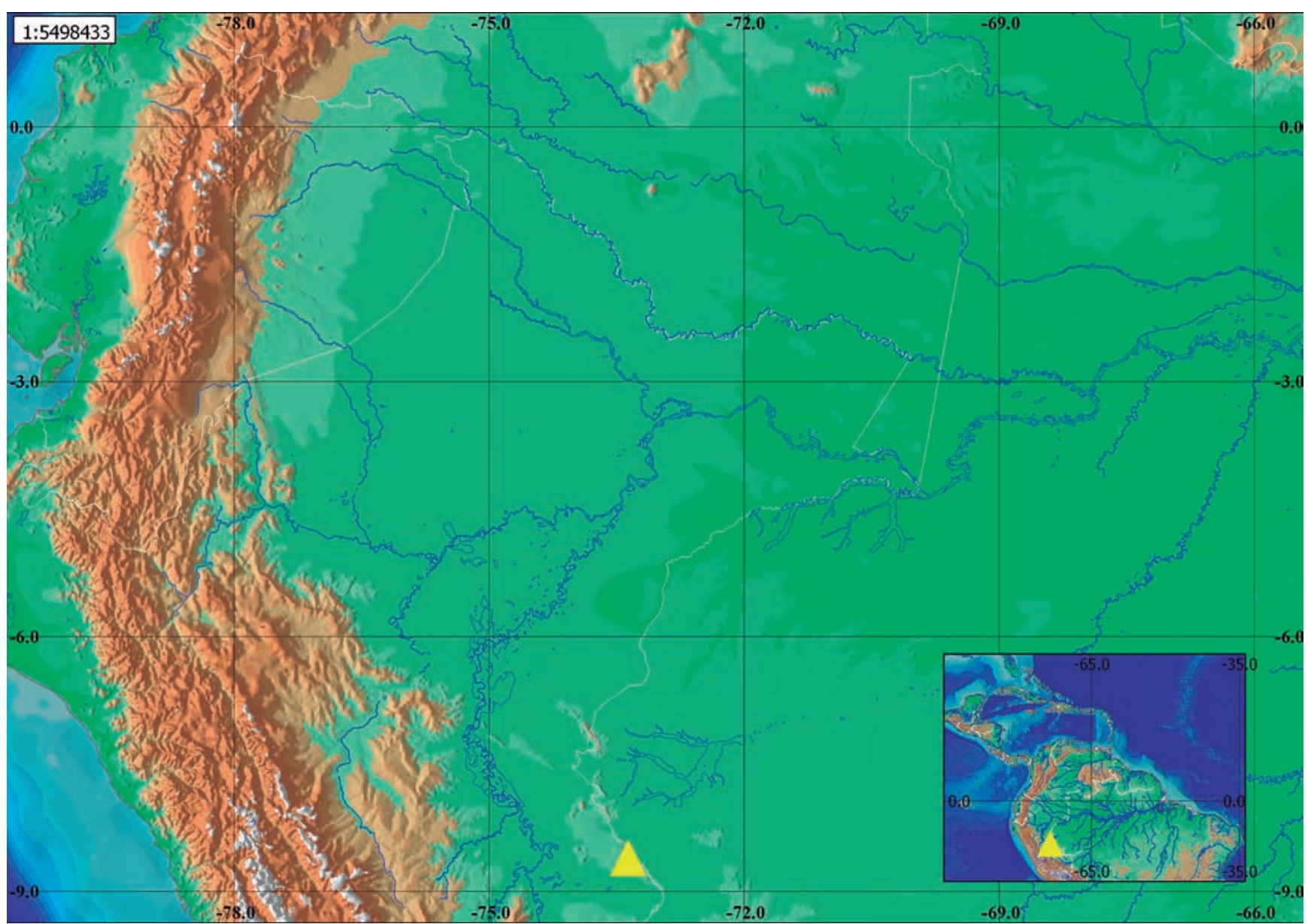

Fig. 5. Geographic distribution of Chrysobrycon yoliae (yellow triangle).

composed of palms named "aguaje" (Mauritia flexuosa), palms locally named "pona" (Socratea exorrhiza) and others small plants. The fish samples were obtained from shallow areas with vegetation, rifles, or rapids along $250 \mathrm{~m}$.

Etymology. The new species name yoliae is matronym in honor and gratitude to "Yoli" (Yolanda Ríos Nossa), the mother of the senior author and who has patiently encouraged and supported his academic formation in all senses.

\section{Key to Chrysobrycon species}

1a. Thirty three to 39 branched anal-fin rays; 17-19 circumpeduncular scales; adult males with a longer and expanded anal fin and with a series of spinelets developed on pelvic-, anal- and caudal-fin rays.

Chrysobrycon myersi

1b. Twenty four to 32 branched anal-fin rays; 14-16 circumpeduncular scales; adult males with shorter and not expanded anal fin and without spinelets on the rays of fins ...

2a. Adult males with a series of minute bony hooks more distally located on almost all anal-fin rays; larger specimens (usually $>50 \mathrm{~mm} \mathrm{SL}$ ) with anteriormost maxillary tooth usually pentacuspidate (rarely tetracuspidate); terminal lateral-line tube on middle caudal-fin rays absent. .Chrysobrycon hesperus

$2 b$. Adult males without a series of minute bony hooks on distal portion of anal-fin rays; larger specimens (usually $>30 \mathrm{~mm}$ SL) with anteriormost maxillary tooth usually tricuspidate (rarely conical, bicuspidate or tetracuspidate); terminal lateralline tube on middle caudal-fin rays present. . .3

3a. Dentary teeth 20-26; depth at dorsal-fin origin 34.4-42.2\% SL; dorsal-fin to adipose-fin length $26.8-28.8 \%$ SL; dorsalfin origin situated at vertical between anal-fin rays 5 to 7 ; posterior extent of ventral process of quadrate reaching the vertical through posterior margin of symplectic (Fig. 6a)...... .Chrysobrycon yoliae new species 3b. Dentary teeth 12-19; depth at dorsal-fin origin 24.1-34.5\% SL; dorsal-fin to adipose-fin length $23.9-26.8 \%$ SL; dorsalfin origin situated at vertical between anal-fin rays 8 to 10 ; posterior extent of ventral process of quadrate not reaching the vertical through posterior margin of symplectic (Fig. 6b)

...Chrysobrycon eliasi 


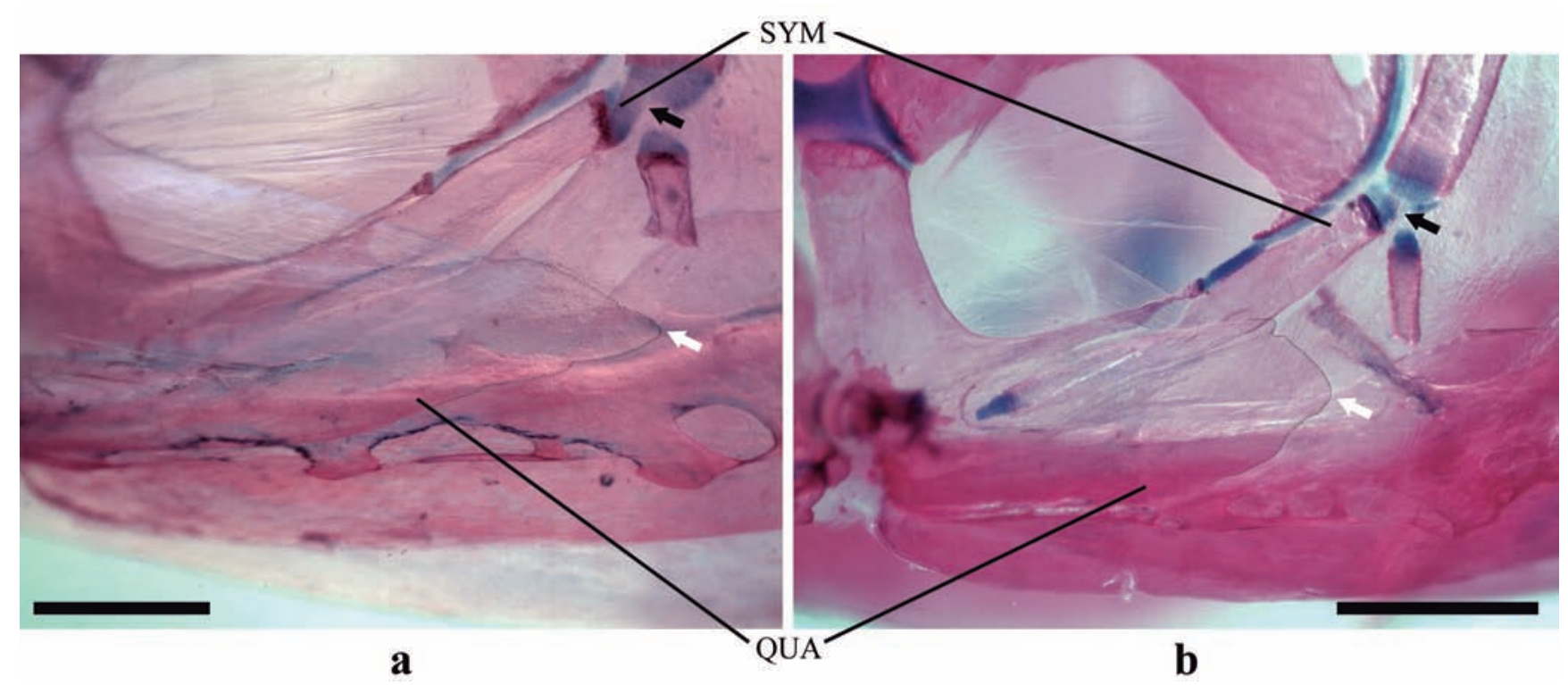

Fig. 6. Detail of suspensorium of (a) Chrysobrycon yoliae, CI-FML 5882, paratype male, $44.8 \mathrm{~mm}$ SL, and (b) Chrysobrycon eliasi, paratype male, AI 287, $39.9 \mathrm{~mm} \mathrm{SL}$, comparing the posterior extent of ventral process of quadrate (QUA, white arrows) with respect to the vertical through posterior margin of symplectic (SYM, black arrows). Anterior to left. Scale bar $=1 \mathrm{~mm}$.

\section{Discussion}

Chrysobrycon is a basal member of the tribe Xenurobryconini, phylogenetically diagnosed by the presence of a single large pouch scale with or without hypertrophied radii (Weitzman $\&$ Menezes, 1998). This is the only character supporting the position of Chrysobrycon within the tribe. The phylogeny and classification of the Xenurobryconini proposed by Weitzman \& Menezes (1998) has been maintained in subsequent and related phylogenetic analyses mainly based on morphology (e.g., Castro et al., 2003; Mirande, 2010; Ferreira et al., 2011).

Weitzman et al. (2005) considered that the origin of the pouch scale within the Xenurobryconini is homologous with that of the group named Stevardiini by Menezes \& Weitzman (2009). Weitzman et al. (2005) stated that the pouch scale of mature males originates from the horizontal scale row just ventral to the lateral-line scale row. In Chrysobrycon species, the pouch scale seems to adjust to this pattern proposed by Weitzman et al. (2005).

We revised the morphology of the pouch opening of all species of Chrysobrycon and found some details not previously described in the literature (Weitzman \& Thomerson, 1970; Weitzman \& Menezes, 1998; Vanegas-Ríos et al., 2011). Species of Chrysobrycon are known by the possession of a single pouch scale and an additional scale situated under it, named in this paper as medial accessory scale (Weitzman \& Menezes, 1998; Vanegas-Ríos et al., 2011). In addition to this, we found a lateral accessory scale that is located lateral to the pouch scale. Although this accessory scale has been illustrated in some figures presented by Weitzman \& Thomerson (1970),
Weitzman \& Menezes (1998), and Vanegas-Ríos et al. (2011), some of its anatomical features related to the pouch scale have not been described in detail before. In a few mature males of $C$. hesperus and C. myersi, we observed a third accessory scale medially located on the posterior portion of the pouch scale, but its presence was variable through samples examined.

In mature males of Chrysobrycon eliasi, C. hesperus, and C. yoliae, the pouch scale and the lateral accessory scale are independent but in contact, with their dorsal borders strongly attached to each other through a variably developed mass of connective tissue. In matures males of $C$. myersi, the lateral accessory scale is short and without contact with the pouch scale, although both scales are connected through a soft portion of connective tissue in comparison with its congeners.

The presence of these types of accessories scales has a variable distribution among species of Stevardiinae with pouch scale in mature males. Some species of the Xenurobryconini have at least one accessory scale in mature males (e.g., Argopleura Eigenmann, Weitzman \& Fink, 1985: 22); in this tribe, additionally, the term "accessories scales" was used for the scales situated posteroventral to the pouch scale (in a different position with respect to the accessories scales in Chrysobrycon species). In mature males of Pseudocorynopoma heterandria Eigenmann (Weitzman \& Menezes, 1998: fig. 6), the pouch scale is accompanied by at least one ventral scale that may be interpreted as an accessory scale. In contrast, mature males of some species of Gephyrocharax Eigenmann, Pterobrycon myrnae Bussing and P. landoni Eigenmann (Bussing, 1974: figs. 5 and 6; Vanegas-Ríos et al., 2013a: fig. 4) do not have these types of 
accessories scales accompanying the pouch scale. Based on these observations, the presence of accessories scales is not completely congruent with the presence of the pouch scale. However, the homology among these types of accessories scales still needs to be investigated in detail, which is beyond the scope of this study.

Comparative material. Chrysobrycon eliasi: Peru: all type and nontype specimens cited by Vanegas-Ríos et al. (2011). Chrysobrycon hesperus: Colombia: ICNMHN 11002, 1, 39.38 mm SL, Putumayo, Orito, Quebrada La Guara, río Putumayo basin, approximately 0³6'00”'N 7652'15.00”W, 344 m a.s.l. Ecuador: ANSP 75912, 1 paratype, $77.4 \mathrm{~mm}$ SL, upper río Villano near Villano, upper río Napo basin, $1^{\circ} 30^{\prime} \mathrm{S} 77^{\circ} 28^{\prime} \mathrm{W}$. ANSP 79513, 1 paratype, $67.4 \mathrm{~mm}$ SL, upper río Villano, near Villano, upper río Napo system, $1^{\circ} 30^{\prime} \mathrm{S} 77^{\circ} 28^{\prime} \mathrm{W}$. ANSP 75914,1 paratype, $63.2 \mathrm{~mm}$ SL, río Suno near mouth, tributary upper río Napo, $0^{\circ} 42^{\prime} \mathrm{S} 77^{\circ} 8^{\prime} \mathrm{W}, 300-320 \mathrm{~m}$ a.s.l. ANSP 79159, 2 paratypes, 60.3-76.0 mm SL, río Pucuno, a tributary of río Suno, upper río Napo system, approximately 350 m a.s.l. USNM 164042, 1 paratype, $70.5 \mathrm{~mm}$ SL, Napo-Pastaza, río Villano, upper Curaray, near Villano, $1^{\circ} 30^{\prime} \mathrm{S} 77^{\circ} 28^{\prime} \mathrm{W}$, approximately $375 \mathrm{~m}$ a.s.l. USNM 164056, holotype of Hysteronotus hesperus Böhlke, 1958, $72.3 \mathrm{~mm}$ SL (radiograph), Napo-Pastaza, río Pucuno, tributary of río Suno, Pucuno, enters of Suno, $0^{\circ} 46^{\prime} \mathrm{S} 77^{\circ} 12^{\prime} \mathrm{W}$, approximately 300-350 m a.s.l. USNM 175124, 1 paratype, $59.1 \mathrm{~mm}$ SL (radiograph), NapoPastaza, río Pucuno, tributary of río Suno, Pucuno, enters of Suno, 346'S 17²12'W. Peru: MUSM 26607, 2, 59.9-66.1 mm SL, Loreto, upper Amazon basin, Andoas, río Corrientes basin, Quebrada Caballo, 2³3'41.17' S 76 13'45.32”'W, 209 m a.s.1. MUSM 26617, 2, 29.8-33.1 $\mathrm{mm}$ SL, Loreto, upper Amazon basin, río Corrientes, drainages flowing into Quebrada Huayuri, 2³5'51.05”'S 76¹3'53.31’W, 208 m a.s.1. MUSM 28640, 2, 25.5-27.0 mm SL, Quebrada Forestal, río Corrientes basin, 2॰19'13.79'"S 76¹0'30.55'W, 215 m a.s.1. MUSM 28665, 3, 36.2-54.6 mm SL (1 c\&s, 54.6 mm SL), Loreto, upper Amazon basin, Andoas, río Corrientes basin, Quebrada Forestal, 2²1'27.71”S 769'25.34'W, 237 m a.s.1. MUSM 28682, 3, 41.6-46.1 mm SL, Loreto, upper Amazon basin, Andoas, Quebrada San Carlos, flowing into río Manchari, 2²4'34.59'S 766’35.69'W, 196 m a.s.l. MUSM 32124, 1, $27.1 \mathrm{~mm}$ SL, Loreto, upper Amazon basin, Andoas, río Corrientes basin, río Platanoyacu, 38'26.54'’S 7545'8.65'W, 153 m a.s.l. MUSM 33159, 2, 29.3-43.9 mm SL, Loreto, upper Amazon basin, Andoas, río Pastaza, Quebrada Carmen, 2²2'43.85”S 769'44.12”W, 216 m a.s.l. Chrysobrycon myersi: Peru: ANSP 112325, 2 paratypes, 30.1-46.1 mm SL, Huanuco, small creek at northeastern outskirts of Tournavista, tributary of río Pachitea. ANSP 112326, 3 paratypes, 28.3-32.0 mm SL, Huanuco, small creek at northeastern outskirts of Tournavista, tributary of río Pachitea. LACM 37720-4, 3, 34.3-63.8 mm SL, Pasco, Iscozacin Valley, Pan de Azúcar, stream about 100 yards above entrance into río Iscozacin. MUSM 12040, 1, 29.7 mm SL, Cusco, La Convención, Echarate, río Urubamba basin, río Picha, Cocha Kamariampiveni, approx $11^{\circ} 36^{\prime}$ 00'S $73^{\circ} 05^{\prime} 00^{\prime}$ 'W, 380 m a.s.l. MUSM 18908, 2, 42.4-48.6 mm SL, Pasco, Oxapampa. Puerto Bermudez, río Pachitea basin, Quebrada Atas, approx 10¹7'47S 7456'11.04'W, $259 \mathrm{~m}$ a.s.1. MUSM 36068, 1, 31.6 mm SL, Curso, La Convencion, Echarate, río Urubamba basin, río Parotori system, río Poyiriari, $12^{\circ} 10^{\prime} 43.96$ 'S 735'6.15”W, 544 m. a.s.1. MUSM 36084, 3, 37.1-58.7 mm SL, Cusco, La Convención, Echarate, Urubamba basin, río Parotori system, río Poyriari, $12^{\circ} 10^{\prime} 44.61^{\prime \prime S} 73^{\circ} 5^{\prime} 18.18^{\prime \prime} \mathrm{W}, 585 \mathrm{~m}$ a.s.1. MUSM 36109 , 2, 32.8-36.3 mm SL, Cusco, La Convención, Echarate, río Urubamba, río Parotori, río Poyiriari, Quebrada Piriabindeni, $12^{\circ} 1^{\prime} 13.05^{\prime \prime} \mathrm{S} 73^{\circ}$ 0’23.59” W, 585 m a.s.1. MUSM 36125, 3, 29.2-38.6 mm SL, Cusco, La Convención, Echarate, río Parotori, Quebrada Piriabindeni, 12॰1'19.29”'S 734'14.66”'W, 545 m a.s.1. MUSM 37889, 2, 45.1$51.0 \mathrm{~mm}$ SL, Junin, Satipo, Mashira, río Tambo basin, Quebrada

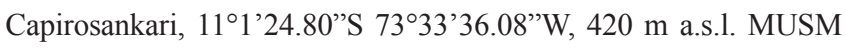
37933, 3, 58.0-60.8 mm SL, Cusco, La Convención, Echarate,

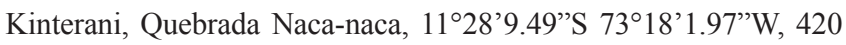
m a.s.1. MUSM 38671, 3, 50.9-60.7 mm SL (1 c\&s, 58.6 mm SL), Junín, Satipo, río Tambo basin, Quebrada Pukakunga, 73²8’2.19”W $11^{\circ} 24^{\prime} 37.27^{\prime}$ 'S, $587 \mathrm{~m}$ a.s.1. USNM 203697, holotype of Hysteronotus myersi Weitzman \& Thomerson, 1970, 46.5 mm SL, Huanuco, small stream directly tributary to río Pachitea (itself tributary to río Ucayali) at northeastern outskirt of Tournavista. USNM 203698, 6 paratypes, 24.9$31.3 \mathrm{~mm}$ SL (one radiograph, $31.3 \mathrm{~mm} \mathrm{SL}$ ), collected with holotype.

\section{Acknowledgments}

We thank the members of the ichthyology lab at MUSM for their help and collaboration, especially to Vanessa MezaVargas and Max Hidalgo, and the following individuals and institution for assistance and support: John Lundberg, Mark Sabaj Pérez, Mariangeles Arce and Kyle Luckenbill (ANSP), and Rick Feeny (LACM); Richard Vari, Stanley Weitzman, Sandra Raredon, Kris Murphy, Jeff Clayton, Jeff Williams, and Lisa Palmer (USNM); and Saul Prada (MUPJ). We also thank the anonymous reviewers, the editor and Juan Mirande, who provided valuable comments on a previous version of the manuscript, and Bruno Pianzola for help with the photographs of the holotype and the paratype. J.A.V-R is grateful by the funding granted as part of a Fellowship program (through of Richard Vari) from the National Museum of Natural History, Smithsonian Institution. This study benefited from a LatinAmerican grant CONICET-Argentina and financial support from the Project 2814 (J.A.V-R.), Fundación para Promoción de la Investigación y la Tecnología, Banco de la República, Colombia. For financial support CONICET and ANPCYT (PICT 913, M.M.A. PICT 2011-0992, J. M. Mirande).

\section{Literature Cited}

Böhlke, J. 1958. Studies on Fishes of the family Characidae. $\mathrm{N}^{\circ} 14$. A report on several extensive recent collections from Ecuador. Proceedings of the Academy of Natural Sciences of Philadelphia, 110: 1-121.

Bussing, W. A. 1974. Pterobrycon myrnae, a remarkable new 
glandulocaudine characid fish from Costa Rica. Revista de Biología Tropical, 22: 135-159.

Castro, R. M. C., A. C. Ribeiro, R. C. Benine \& A. L. A. Melo. 2003. Lophiobrycon weitzmani, a new genus and species of glandulocaudine fish (Characiformes: Characidae) from the rio Grande drainage, upper rio Paraná system, southeastern Brazil. Neotropical Ichthyology, 1: 11-19.

Ferreira, K. M., N. A. Menezes \& I. Quagio-Grassioto. 2011. A new genus and two new species of Stevardiinae (Characiformes: Characidae) with a hypothesis on their relationships based on morphological and histological data. Neotropical Ichthyology, 9: 281-298.

Fink, W. L. \& S. H. Weitzman. 1974. The so-called cheirodontin fishes of central America with descriptions of two new species (Pisces: Characidae). Smithsonian Contributions to Zoology, 172: 1-46.

Hammer, Ø., D. A. T. Harper \& P. D. Ryan. 2001. PAST: Paleontological Statistics Software Package for Education and Data Analysis. Palaeontologia Electronica, 4: 1-9. Available from: http://palaeo-electronica.org/2001 1/past/issue1 01.htm

Menezes, N. A. \& S. H. Weitzman. 2009. Systematics of the Neotropical fish subfamily Glandulocaudinae (Teleostei: Characiformes: Characidae). Neotropical Ichthyology, 7: 295-370.

Mirande, J. M. 2010. Phylogeny of the family Characidae (Teleostei: Characiformes): from characters to taxonomy. Neotropical Ichthyology, 8: 385-568.

Taylor, W. R. \& G. C. Van Dyke. 1985. Revised procedures for staining and clearing small fishes and other vertebrates for bone and cartilage study. Cybium, 9: 107-119.

Vanegas-Ríos, J.A. M. M. Azpelicueta \& H. Ortega. 2011. Chrysobrycon eliasi, new species of stevardiine fish (Characiformes: Characidae) from the río Madre de Dios and upper río Manuripe basins, Peru. Neotropical Ichthyology, 9: 731-740.
Vanegas-Ríos, J. A., M. M. Azpelicueta, J. M. Mirande \& M. D. G. Gonzales. 2013a. Gephyrocharax torresi (Characiformes: Characidae: Stevardiinae), a new species from the río Cascajales basin, río Magdalena system, Colombia. Neotropical Ichthyology, 11: 275-284.

Vanegas-Ríos, J. A., V. Mesa-Vargas \& M. M. Azpelicueta. 2013b. Extension of geographic distribution of Chrysobrycon hesperus and C. myersi (Characiformes, Characidae, Stevardiinae) for several drainages flowing into the río Amazonas basin in Peru and Colombia. Revista Mexicana de Biodiversidad, 84: 384-387.

Weitzman, S. H. \& N. A. Menezes. 1998. Relationships of the tribes and genera of the Glandulocaudinae (Ostariophysi: Characiformes: Characidae) with a description of a new genus, Chrysobrycon. Pp. 171-192. In: Malabarba, L. R., R. E. Reis, R. P. Vari, Z. M. S. Lucena \& C. A. S. Lucena (Eds.). Phylogeny and Classification of Neotropical Fishes. Porto Alegre, Edipucrs.

Weitzman, S. H., N. A. Menezes, J. R. Burns \& H-Georg Evers. 2005. Putative relationships among inseminating and externally fertilizing characids, with a description of a new genus and species of Brazilian inseminating fish bearing an anal-fin gland in males (Characiformes: Characidae). Neotropical Ichthyology, 3: 329-360.

Weitzman, S. H. \& J. E. Thomerson. 1970. A new species of glandulocaudine characid fish, Hysteronotus myersi, from Peru. Proceedings of the California Academy of Sciences, 38: 139-156.

Submitted July 23, 2013

Accepted January 10, 2014 by George Mattox

Published June 30, 2014 